Article

\title{
Evaluation of Resistance Sources of Tomato (Solanum lycopersicum L.) to Phylotype I Strains of Ralstonia solanacearum Species Complex in Benin
}

\author{
Herbaud Zohoungbogbo ${ }^{1, *(D)}$, Adonis Quenum ${ }^{2}$, Judith Honfoga ${ }^{1}$, Jaw-Rong Chen ${ }^{3}$, Enoch Achigan-Dako ${ }^{2}(\mathbb{D}$, \\ Lawrence Kenyon $^{3}$ (D) and Peter Hanson 1,3 (D) \\ 1 World Vegetable Center, West and Central Africa-Coastal and Humid Regions, IITA-Benin Campus, \\ Cotonou 08 BP 0932, Benin; judith.honfoga@worldveg.org (J.H.); peter.hanson@worldveg.org (P.H.) \\ 2 Laboratory of Genetics, Biotechnology and Seed Science, Faculty of Agronomic Sciences, \\ University of Abomey-Calavi, Abomey-Calavi BP 2549, Benin; quenumad@gmail.com (A.Q.); \\ e.adako@gmail.com (E.A.-D.) \\ 3 World Vegetable Center, Shanhua, Tainan 74151, Taiwan; jaw-rong.chen@worldveg.org (J.-R.C.); \\ lawrence.kenyon@worldveg.org (L.K.) \\ * Correspondence: herbaud.zohoungbogbo@worldveg.org
}

\section{check for}

updates

Citation: Zohoungbogbo, H.; Quenum, A.; Honfoga, J.; Chen, J.-R.; Achigan-Dako, E.; Kenyon, L.; Hanson, P. Evaluation of Resistance Sources of Tomato (Solanum lycopersicum L.) to Phylotype I Strains of Ralstonia solanacearum Species Complex in Benin. Agronomy 2021, 11, 1513. https://doi.org/10.3390/ agronomy 11081513

Academic Editor: Alan Walters

Received: 15 June 2021

Accepted: 24 July 2021

Published: 29 July 2021

Publisher's Note: MDPI stays neutral with regard to jurisdictional claims in published maps and institutional affiliations.

Copyright: (c) 2021 by the authors. Licensee MDPI, Basel, Switzerland. This article is an open access article distributed under the terms and conditions of the Creative Commons Attribution (CC BY) license (https:// creativecommons.org/licenses/by/ $4.0 /$ )
Abstract: Finding sources of resistance to bacterial wilt (BW) caused by Ralstonia solanacearum species complex is a crucial step toward the development of improved bacterial wilt-resistant tomato varieties. Here, we evaluated new sources of bacterial wilt-tolerant/resistant tomato lines and identified associated phylotype/sequevar of R. solanacearum strains in Benin. Eighteen F5 lines and five checks were evaluated in two hotspots: the experimental site of the World Vegetable Center, Cotonou Benin, and the Laboratory of Genetics, Biotechnology and Seed Science of the University of Abomey-Calavi. Experiments were laid out in a randomized complete block design with four replicates. Data were collected on bacterial wilt incidence, horticultural and fruit traits and yield components. Across the two experiments, the F5 lines showed no wilting, while the local variety 'Tounvi' used as susceptible check showed $57.64 \%$ wilting. The wilting was due to BW and was associated with sequevars I-14, I-18 and I-31 of phylotype I. AVTO1803, AVTO1955-6 and H7996 were the highest yielding lines with $20.29 \mathrm{t} \cdot \mathrm{ha}^{-1}, 17.66 \mathrm{t} \cdot \mathrm{ha}^{-1}$ and $17.07 \mathrm{t} / \mathrm{ha}$, respectively. The sources of resistance to $\mathrm{BW}$ can be recommended to national agricultural system for dissemination or used in tomato breeding programs.

Keywords: tomato; bacterial wilt; resistance; phylotype I and sequevars

\section{Introduction}

Tomato (Solanum lycopersicum L.) is an important vegetable crop in West Africa with a total production of $\sim 5,201,574$ metric tons harvested from 1,005,958 hectares in 2019 [1]. In Benin, tomato is the main vegetable crop with an average yield of $7.29 \mathrm{t} \cdot \mathrm{ha}^{-1}$ in 2019 [1] and is an important source of income for farmers [2,3]. However, tomato production in Benin is limited by bacterial wilt (BW) disease caused by the Ralstonia solanacearum species complex (RSSC) that reduces crop yields and farmers' incomes. The pathogen was identified in all tomato production areas [4] with the highest BW incidence recorded in southern Benin, particularly in periodically flooded areas, where more than $70 \% \mathrm{BW}$ incidence occurred [4].

RSSC ranks among the most devastating pathogens in solanaceous crops. The RSSC are soil-borne bacteria which can attack $>450$ plant species in 50 families, including tomato, pepper, potato, tobacco, eggplant, ginger, banana and several other economically important crops [5]. RSSC is able to survive, rapidly disseminate or adapt to different ecological niches including soil, water and plant (nonhost rhizosphere and host xylem) [6]. RSSC strains have been grouped into the $R$. solanacearum species complex consisting of four major phylotypes broadly based on geographical origins: I (Asia), II (American), III (Africa 
and the Indian Ocean) and IV (Indonesia, Australia, Japan) and classified by analyses of sequence data generated from the 16S-23S internal transcribed spacer (ITS) region [7]. More recently, the RSSC was taxonomically organized into three species that classified phylotypes I and III as R. pseudosolanacearum, phylotype II as R. solanacearum and phylotype IV as $R$. syzygii [8,9]. The phylotypes are subdivided into sequevars based on sequence variation in the endoglucanase (egl) partial gene [7]. Phylotype I is known for its broad intrasubspecific diversity and comprises 16 out of the 57 sequevars that are currently known [10].

Many studies have reported the presence of bacterial wilt caused by RSSC in West Africa. Phylotypes I, II and III are present in the region but phylotype I is the most predominant in West Africa, especially in Benin, Togo, Côte d'Ivoire, Mali, Nigeria and Ghana $[4,11-14]$. Crop sanitation, disease-free planting material, crop rotation and grafting are tactics used to manage BW, but each has its own disadvantages or drawbacks and seldom work as a stand-alone control method. Continual use of disease-free planting material and crop sanitation can be a challenge for West African farmers who sometimes consider these activities as too time consuming. Resistant varieties, if available, could contribute significantly to BW management, but plant breeders face numerous challenges to develop such varieties. Resistance to bacterial wilt in tomato is quantitative, and is strongly influenced by environmental conditions such as soil temperature, $\mathrm{pH}$ and moisture [15]. Even when resistance is effective, it is typically strain- or location-specific [16,17], and the diversity of pathogenic strains of RSSC has led to the development of resistant lines that are not durable over diverse geographic regions [18]. Another issue that has been problematic for tomato breeders is that small fruit size is linked to resistance to bacterial wilt $[19,20]$.

Identification of resistance sources is a critical step in developing BW-resistant varieties for Benin and possibly other parts of West Africa. Multiple trials conducted by WorldVeg in south Benin revealed that Hawaii 7996 (H7996) seldom developed wilting; H7996 was among the best BW resistance sources identified after multilocation testing in Asia [17]. However, H7996 has many undesirable fruit and horticultural traits and it is unsuitable for direct use as a variety. Mapping studies of this source identified two major genomic regions (Bwr-12 and Bwr-6) conditioning BW resistance, as well as additional QTLs with minor or strain-specific effects [21]. Bwr-12 is located in a $2.3 \mathrm{cM}$ interval of chromosome 12 , that accounted for much of the phenotypic variation for resistance to the phylotype I isolates. Bwr-6 encompasses a $15.5 \mathrm{cM}$ region on chromosome 6 that may include one or more QTLs important for resistance to phylotype II isolates [21]. Markers linked to Bwr-12 and Bwr-6 have been developed [22] and are routinely used in breeding at WorldVeg and other institutions. Trials in south Benin of WorldVeg tomato lines bred in Taiwan revealed that lines homozygous for only Bwr-12 showed only partial BW resistance with significant incidences of wilting compared to H7996. WorldVeg lines homozygous for Bwr-12 and Bwr-6 generally offered higher BW resistance than lines with Bwr-12 alone but often did not show resistance levels equal to H7996, suggesting that H7996 possesses additional BW resistance QTL besides Bwr-12 and Bwr-6 [5,23]. Efforts to map additional BW resistance QTL in H7996 are ongoing as well as to use this source in breeding.

BW pressure is high in many parts of Indonesia where isolates of R. syzygii (phylotype IV) are common [24]. A commercial tomato hybrid called 'Servo' from East-West Seed has shown excellent bacterial wilt resistance in Indonesia, but the variety is not marketed in Benin. Through a combination of marker-assisted selection and greenhouse BW tests, WorldVeg tomato breeding developed a set of F5 lines derived from Servo. In this study, we evaluated new sources of BW resistance in order to identify BW-resistant lines that could be candidates for use as open-pollinated varieties and used as BW resistance sources in breeding in Benin and in other parts of West Africa. Specifically, we aimed to (I) evaluate the BW reaction and agronomic performances of the F5 lines in Benin and (II) identify the RSSC strains present in these trials. We hypothesize that (I) the F5 lines are highly resistant/tolerant to BW with good agronomic performances compared to the checks and (II) phylotype I strains were the most prevalent in this study. 


\section{Materials and Methods}

\subsection{Development of $F_{5}$ Lines Derived from Servo}

In $2017,384 \mathrm{~F}_{2}$ plants from seed obtained by self-pollination of Servo were grown at the World Vegetable Center (Shanhua, Tainan, Taiwan) and subjected to marker-assisted selection for Bwr-6 using markers SLM6-17, SLM6-94 and SLM6-110; the population was homozygous for Bwr-12. A total of $41 \mathrm{~F} 2$ plants homozygous for the resistance gene at SLM6-17, SLM6-94 and SLM6-110 at Bwr-6 were selected and transplanted to a WorldVeg field in January 2018, and subsequently evaluated for fruit set, fruit and horticultural traits during the spring season (January-June). Twenty-one F2 plants were selected and F3 seeds were harvested from individual plants. The 21 F3 families were screened in the greenhouse by seedling drench inoculation for resistance to one phylotype I isolate (Pss4) and one phylotype II isolate (Pss1632) in separate trials. The F3 families were advanced to the F5 by pedigree selection during the 2019 spring and fall seasons. Seeds of $18 \mathrm{~F}_{5: 6}$ lines were shipped to WorldVeg Benin on 31 January 2020.

\subsection{Evaluation of the F5 Lines and Checks for BW Resistance}

Twenty-three tomato lines were evaluated for bacterial wilt resistance (Table 1) in this study. Eighteen entries coded AVTO1955 were $\mathrm{F}_{5}$ lines derived from Servo and selected at WorldVeg. CLN1621L and AVTO1803 are WorldVeg lines homozygous for Bwr-12 and Bwr-6, respectively. H7996 and CRA66 are BW-resistant checks, and Tounvi is a susceptible tomato variety from Benin.

Table 1. List of tomato entries characterized for presence of bacterial wilt genes $B w r-12$ and $B w r-6$.

\begin{tabular}{|c|c|c|c|c|c|}
\hline \multirow{2}{*}{ Code } & \multirow{2}{*}{ Entries } & \multirow[t]{2}{*}{ Bwr-12 } & \multicolumn{3}{|c|}{ Bwr-6 } \\
\hline & & & SLM6-17 & SLM6-94 & SLM6-110 \\
\hline $\mathrm{T} 1$ & AVTO1955-1 & + & + & + & + \\
\hline $\mathrm{T} 2$ & AVTO1955-2 & + & + & + & + \\
\hline T3 & AVTO1955-3 & + & + & + & + \\
\hline $\mathrm{T} 4$ & AVTO1955-5 & + & + & + & + \\
\hline T5 & AVTO1955-6 & + & + & + & + \\
\hline T6 & AVTO1955-9 & + & + & + & + \\
\hline $\mathrm{T} 7$ & AVTO1955-10 & + & + & + & + \\
\hline T8 & AVTO1955-11 & + & + & + & + \\
\hline T9 & AVTO1955-12 & + & + & + & + \\
\hline T10 & AVTO1955-14 & + & + & + & + \\
\hline T11 & AVTO1955-15 & + & + & + & + \\
\hline T12 & AVTO1955-16 & + & + & + & + \\
\hline T13 & AVTO1955-17 & + & + & + & + \\
\hline T14 & AVTO1955-18 & + & + & + & + \\
\hline $\mathrm{T} 15$ & AVTO1955-19 & + & + & + & + \\
\hline T16 & AVTO1955-20 & + & + & + & + \\
\hline T17 & AVTO1955-21 & + & + & + & + \\
\hline T18 & AVTO1955-22 & + & + & + & + \\
\hline T19 & CLN1621L & + & - & - & - \\
\hline T20 & Tounvi & - & - & - & - \\
\hline $\mathrm{T} 21$ & Hawaii7996 & + & + & + & + \\
\hline T22 & CRA66 & + & + & + & + \\
\hline $\mathrm{T} 23$ & AVTO1803 & + & + & + & + \\
\hline
\end{tabular}

Key: + homozygous for resistance allele, - homozygous susceptible allele, Bwr-12 and Bwr-6 genes conditioning bacterial wilt resistance.

\subsection{Trial Sites}

Experiments were conducted on fields of the World Vegetable Center-Benin (WorldVeg) and the experimental site of the Laboratory of Genetics, Biotechnology and Seed Science (GBioS) of the University of Abomey-Calavi during the 2020 rainy season (April to September). The two sites are known for their high infestation with RSSC and the high 
bacterial wilt incidence found in previous tomato cultivations. Soil $\mathrm{pH}$ recorded on the WorldVeg and GBioS sites were 5.53 and 5.5, respectively. Weather data during the trials are reported in Table 2.

Table 2. Weather data recorded from April-September 2020 at Abomey-Calavi.

\begin{tabular}{ccccccc}
\hline Weather Parameters & April & May & June & July & August & September \\
\hline Total Rainfall $(\mathrm{mm})$ & 119 & 123.8 & 561.9 & 44.9 & 0 & 203.6 \\
Total Evaporation $(\mathrm{mm})$ & 145.34 & 136.03 & 91.86 & 98.24 & 129.65 & 93.2 \\
Average Rainfall $(\mathrm{mm} /$ day) & 3.97 & 3.99 & 18.73 & 1.44 & 0 & 6.78 \\
Average Min. Temp $\left({ }^{\circ} \mathrm{C}\right)$ & 25.47 & 24.91 & 23.75 & 24.05 & 23.05 & 23.65 \\
Average Max. Temp $\left({ }^{\circ} \mathrm{C}\right)$ & 32.10 & 31.44 & 29.50 & 28.05 & 28.06 & 28.51 \\
Average Min. Rel. $/ \mathrm{Hum}(\%)$ & 65.84 & 70.33 & 77.37 & 76.82 & 70.36 & 73.31 \\
Average Max. Rel./Hum & 92.58 & 94.12 & 96.22 & 93.5 & 89.79 & 90.75 \\
\hline
\end{tabular}

\subsection{Experimental Design and Agronomic Practices}

Treatments in both experiments were laid out in a Randomized Complete Block Design (RCBD), with 5 replications and 12 plants per replication per entry. Between- and within-row spacings were $70 \mathrm{~cm}$ and $50 \mathrm{~cm}$, respectively.

One week after transplanting, poultry manure was applied at a rate of $10 \mathrm{t} / \mathrm{ha}$. Two weeks after transplanting, we applied a balanced fertilizer (N-P-K 15-15-15) at a rate of $200 \mathrm{~kg} / \mathrm{ha}$. At five weeks after transplanting, we applied urea $(46 \% \mathrm{~N})$ and $\mathrm{K}_{2} \mathrm{SO}_{4}$ $(50 \% \mathrm{~K})$ fertilizers at a rate of $100 \mathrm{~kg} / \mathrm{ha}$ each. The pesticides Lambda-cyhalothrin $2.5 \mathrm{EC}$ (Lambdacal), Mancozeb (Idefix at a rate of $2 \mathrm{~kg} / \mathrm{ha}$ ) combined with metalaxyl, Acarus (at a rate of $300 \mathrm{~mL} / \mathrm{ha}$ ) were applied regularly throughout the experiment to manage fungal diseases and pest and mite attacks.

\subsection{Data Collection}

BWI was determined as the ratio of the number of wilted plants to the total number of plants per plot using the following formula:

$$
\mathrm{BWI}=(\mathrm{n} / \mathrm{N}) \times 100,
$$

where $\mathrm{n}$ is the number of completely wilted by BW disease and $\mathrm{N}$ is the total number of plants per plot.

Disease progression was measured for each plant by observing wilt incidence ( \pm wilting) in 1-2-week intervals. Periodically, RSSC presence in wilted plants was confirmed by internal examinations of select stems for vascular browning and bacterial streaming when the cut stem was immersed in a glass of water.

Days to $50 \%$ flowering were recorded as the number of days from sowing until half the plants in a plot had flowered. Fruit characteristics such as fruit weight, fruit length and width were recorded. Fruit weights were obtained by dividing the total fruit weight per plot by the total number of fruits per plot. Fruit length and width were determined by measuring ten fully ripened fruits from the second and third harvests with caliper. Brix was determined using a hand refractometer and values were based on an average of ten fully ripened fruits per entry. Yields were based on five harvests. Total fruit yield was calculated based on the marketable fruit yield and non-marketable fruit yield. We also recorded data on fruit set, average fruit weight per plant, average number of fruits per plant and fruit shape. Total fruit yield $\left(\mathrm{kg} \mathrm{ha}^{-1}\right)$ was calculated based on the weight in kilogram harvested from each plot and converted to tons per hectare $\left(\mathrm{t} \cdot \mathrm{ha} \mathrm{H}^{-1}\right)$ using the following formula:

Yield $\left(\mathrm{t} \cdot \mathrm{ha}^{-1}\right)=\left(\right.$ Yield $(\mathrm{kg})$ of two central rows $\left.\times 10,000 \mathrm{~m}^{2}\right) /$ Net area $\left(\mathrm{m}^{2}\right)$ of the two central rows/plot. 


\subsection{Characterization/Identification of R. solanacearum Complex Species and Phylotypes}

\subsubsection{Collection of Samples}

We collected samples from the 18 tolerant/resistant recombinant inbred lines at the WorldVeg site for RSSC colonization tests to confirm the effective pathogen presence in the lines. All the wilted plants in the both fields were directly collected. Cut stems of wilting tomato which produced bacterial ooze in water and vascular discoloration in longitudinal stem sections were stored. All the wilted samples tested positive to the bacterial cell streaming test and subsamples of each sample were captured directly on separate FTA $^{\mathrm{TM}}$ (Flinder Technology Associates) cards following the protocol used by Burlakoti [25]. Pure cultures with Ralstonia-like morphology and coloring on Tripheny tetrazolium chloride (TZC) medium were isolated from each strain and captured on a separate FTA ${ }^{\mathrm{TM}}$ card and sent to WorldVeg, Taiwan, for sequencing.

\subsubsection{Species and Phylotype Identification}

Species and phylotype identification were performed after DNA isolation from the samples captured on FTA ${ }^{\mathrm{TM}}$ cards. Two-millimeter diameter disks cut from the sampleloaded area of the FTA card using a Harris Uni-Core ${ }^{\mathrm{TM}}-2.00$ punch were placed into separate $1.5 \mathrm{~mL}$ microfuge tubes and washed using purification reagent and $1 \mathrm{x}$ TE buffer following the manufacturer's instruction (Whatman ${ }^{\mathrm{TM}}$ FTA $^{\mathrm{TM}}$ Card Technology) following Burlakoti [25].

\subsection{Data Analysis}

Descriptive statistical analyses were performed. Data were tested for normality of residual errors and homoscedasticity of variances. Analysis of variance and generalized linear models were performed for tomato horticultural and yields traits across sites and varieties following Equation (1).

$$
y_{i j k}=u+g_{i}+s_{j}+g s_{i j}+b(s)_{j k}+\varepsilon_{i j k}
$$

where $u$ is the overall mean, $g_{i}$ is the effect of $i^{\text {th }}$ entry, $e_{j}$ is the effect of $j^{\text {th }}$ site, $b(s)_{j k}$ is the effect of the $k$ th replication within the $\mathrm{j}^{\text {th }}$ site, $\mathrm{gs}_{\mathrm{ij}}$ is the effect of the interaction of the $\mathrm{i}^{\text {th }}$ entry and $\mathrm{j}^{\text {th }}$ site and $\varepsilon_{\mathrm{ijk}}$ is the residual effect.

Linear mixed model with function (lmer) was performed in R software version 3.5.2 [26]. The output of the lmer was subjected to ANOVA III and RANOVA to calculate the mean square of the fixed factor and the level of significance of the random factors, respectively. In the mixed model, entry was considered as fixed, while location, replication and location * entry were considered as random factors. Mean separation among entries was performed using Tukey's mean comparison test $(\alpha=0.05)$ method with function glht (model) and the letter obtained through cld function of package multcomp [27]. Disease incidence data were transformed by arcsin of the square root to normalize the data before applying the generalized linear models.

\section{Results}

\subsection{Bacterial Wilt Incidence and Agronomic Performance of the F5 Lines and Checks}

Analysis of variance of the bacterial wilt incidence did not detect significant difference for the interaction between varieties and location $(p>0.05)$. The F5 lines did not wilt at the two locations while local variety Tounvi showed high sensitivity to bacterial wilt, with more than $50 \%$ of wilted plants across the two locations (Table 3 ). WorldVeg check lines CLN1621L and AVTO1803, homozygous for Bwr-12 and Bwr-6, respectively, showed little sensitivity to bacterial wilt with less than $5 \%$ of wilted plants. Resistant checks CRA66 and H7996 showed no sensitivity to bacterial wilt in the two locations (Figure 1). 


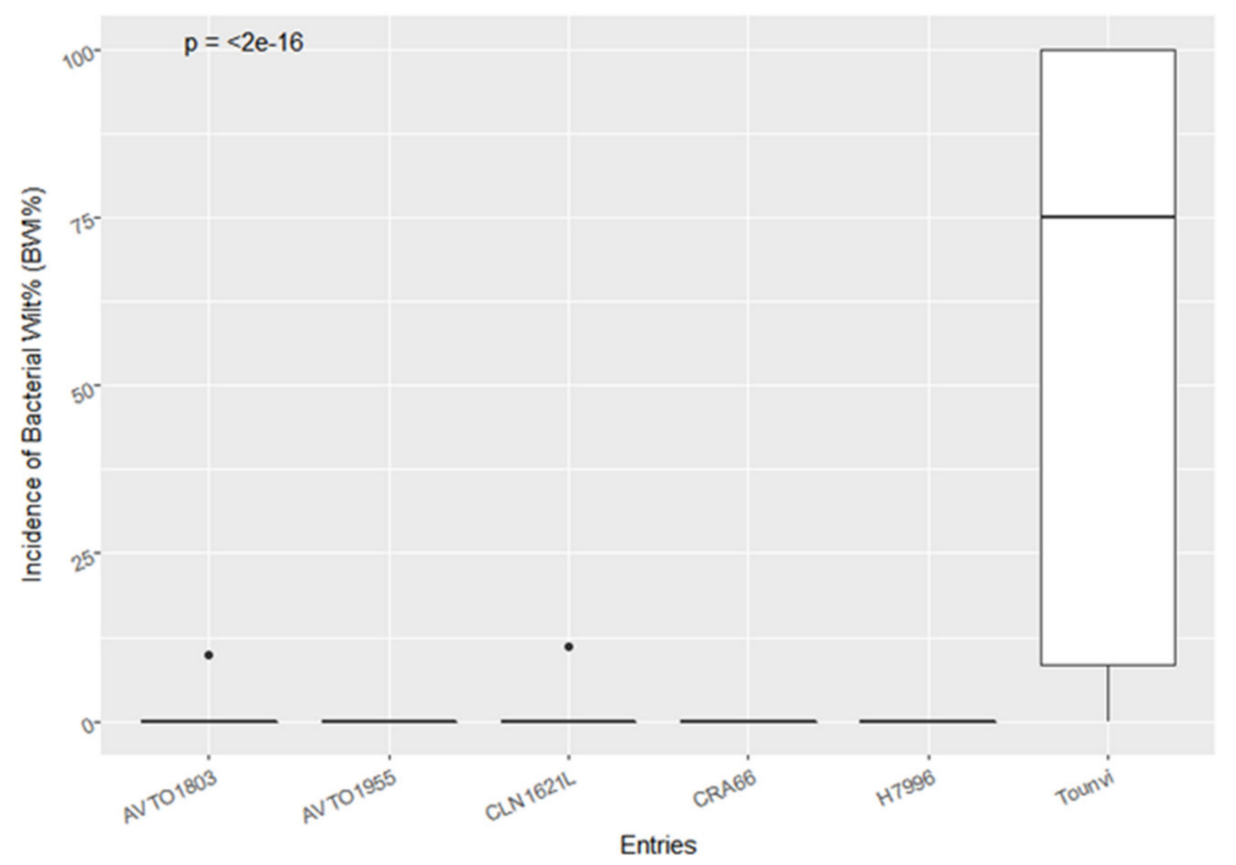

Figure 1. Bacterial wilt incidence comparison between F5 lines and checks.

No significance difference between locations was found for all the traits except for ${ }^{\circ}$ brix content $(p=0.005)$. We observed significant differences among varieties for horticultural traits, yield and yield components. Local variety Tounvi was the earliest flowering entry and reached 50\% flowering 29 days after transplanting. AVTO1955-14 flowered late at about 62 days from sowing to 50\% flowering. Highly significant differences were found among entries for total yield and marketable yield. CLN4018 was the highest yielding line in the trial (20.29 t/ha) and the lowest yielding lines were Tounvi (5.71 t/ha) and AVTO1955-2 (5.31 t/ha). The average total yield over trials was $11.72 \mathrm{t} / \mathrm{ha}$. AVTO1955-6 (17.66 t/ha), AVTO1955-3 (16.44 t/ha) and AVTO1955-14 (14.83 t/ha) were the high-yielding F5 lines while AVTO1955-2 (5.31 t/ha) was the lowest yielding line. Considered as a group, the total yield of the F5 lines (11.05 t/ha) was about twice that of Tounvi (5.71 t/ha) (Figure 2). As a group, the F5 lines developed slightly larger fruit (32.7 g) compared to Tounvi (18 g). CLN4018I produced the highest average fruit weight $(75 \mathrm{~g})$. 
Table 3. Yield, horticultural and fruit traits of F5 lines and checks evaluated at two sites in Benin, 2020.

\begin{tabular}{|c|c|c|c|c|c|c|c|c|c|c|c|}
\hline Entry & $\begin{array}{l}\text { Days to } 50 \% \\
\text { Flowering }\end{array}$ & Fruit Set \% & $\begin{array}{l}\text { Total Yield } \\
\text { (t/ha) }\end{array}$ & $\begin{array}{c}\text { Marketable } \\
\text { (t/ha) }\end{array}$ & $\begin{array}{l}\text { Fruit Length } \\
(\mathrm{mm})\end{array}$ & $\begin{array}{l}\text { Fruit Width } \\
\quad(\mathrm{mm})\end{array}$ & $\begin{array}{c}\text { Ave Fruit } \\
\text { Weight (g) }\end{array}$ & ${ }^{\circ}$ Brix & $\begin{array}{l}\text { Bacterial Wilt } \\
\text { Incidence } \\
\text { (BWI\%) }\end{array}$ & Growth Habit & Fruit Shape \\
\hline AVTO1955-1 & $56 \mathrm{bc}$ & $43 \mathrm{a}$ & $8.15 \mathrm{ac}$ & $8.00 \mathrm{ac}$ & $40 \mathrm{bfg}$ & $33 \mathrm{ab}$ & $26 \mathrm{ab}$ & 5.25 & 0.00 & SD & Oblong \\
\hline AVTO1955-10 & $57 \mathrm{bc}$ & $63 \mathrm{ab}$ & $11.00 \mathrm{acd}$ & 10.87 ace & $51 \mathrm{~d}$ & $42 \mathrm{bc}$ & $46 \mathrm{e}$ & 5.01 & 0.00 & SD & Oblong \\
\hline AVTO1955-11 & $56 \mathrm{bc}$ & $53 \mathrm{ab}$ & $10.28 \mathrm{acd}$ & 10.10 ace & $49 \mathrm{df}$ & $40 \mathrm{ab}$ & 40 ce & 5.43 & 0.00 & I & Oblong \\
\hline AVTO1955-12 & $54 \mathrm{bc}$ & $45 \mathrm{a}$ & 13.15 ae & $13.08 \mathrm{acd}$ & $41 \mathrm{bdf}$ & $34 \mathrm{ab}$ & $33 \mathrm{bc}$ & 4.53 & 0.00 & I & Oblong \\
\hline AVTO1955-14 & $62 \mathrm{~b}$ & $60 \mathrm{ab}$ & 14.83 bce & $14.31 \mathrm{bcd}$ & 44 cdef & $36 \mathrm{ab}$ & $31 \mathrm{bc}$ & 5.30 & 0.00 & I & Oblong \\
\hline AVTO1955-15 & $56 \mathrm{bc}$ & $75 \mathrm{~b}$ & 14.75 bce & $14.65 \mathrm{bcd}$ & 48 cdef & $39 \mathrm{ab}$ & 40 ce & 5.14 & 0.00 & $\mathrm{SD}$ & Oblong \\
\hline AVTO1955-16 & $46 \mathrm{ab}$ & $52 \mathrm{ab}$ & $8.25 \mathrm{ac}$ & $8.14 \mathrm{ac}$ & 48 def & $36 \mathrm{ab}$ & $32 \mathrm{bc}$ & 5.33 & 0.00 & $\mathrm{SD}$ & Oblong \\
\hline AVTO1955-18 & $49 \mathrm{ab}$ & $64 \mathrm{ab}$ & $10.25 \mathrm{acd}$ & 10.14 ace & 49 def & $37 \mathrm{ab}$ & $34 \mathrm{bc}$ & 4.95 & 0.00 & SD & Oblong \\
\hline AVTO1955-19 & $60 \mathrm{~b}$ & $51 \mathrm{ab}$ & $10.29 \mathrm{acd}$ & 10.08 ace & 46 cdef & $34 \mathrm{ab}$ & $31 \mathrm{bc}$ & 5.30 & 0.00 & $\mathrm{SD}$ & Oblong \\
\hline AVTO1955-2 & $49 \mathrm{ab}$ & $39 a$ & $5.31 \mathrm{a}$ & $5.22 \mathrm{a}$ & $37 \mathrm{bc}$ & $32 \mathrm{ab}$ & $23 \mathrm{ab}$ & 5.24 & 0.00 & $\mathrm{SD}$ & Oblong \\
\hline AVTO1955-20 & $43 \mathrm{ab}$ & $45 \mathrm{a}$ & 9.77 acd & 9.41 ace & 49 def & $36 \mathrm{ab}$ & $32 \mathrm{bc}$ & 5.08 & 0.00 & SD & Oblong \\
\hline AVTO1955-21 & $60 \mathrm{~b}$ & $55 \mathrm{ab}$ & 10.24 acd & 10.03 ace & $46 \mathrm{cdef}$ & $36 \mathrm{ab}$ & $33 \mathrm{bc}$ & 4.73 & 0.00 & $\mathrm{SD}$ & Oblong \\
\hline AVTO1955-22 & $54 \mathrm{bc}$ & $62 \mathrm{ab}$ & 9.08 acd & $8.89 \mathrm{ac}$ & $44 \mathrm{bdf}$ & $35 \mathrm{ab}$ & $31 \mathrm{bc}$ & 5.16 & 0.00 & SD & Oblong \\
\hline AVTO1955-3 & $45 \mathrm{ab}$ & $65 \mathrm{ab}$ & $16.44 \mathrm{ce}$ & $16.32 \mathrm{~cd}$ & $43 \mathrm{bdf}$ & $36 \mathrm{ab}$ & 29 ac & 5.57 & 0.00 & $\mathrm{SD}$ & Oblong \\
\hline AVTO1955-5 & $57 \mathrm{bc}$ & $59 \mathrm{ab}$ & 12.05 ae & 11.90 acd & 38 be & $34 \mathrm{ab}$ & $25 \mathrm{ab}$ & 5.21 & 0.00 & $\mathrm{SD}$ & Oblong \\
\hline AVTO1955-6 & $44 \mathrm{ab}$ & $59 \mathrm{ab}$ & $17.66 \mathrm{de}$ & $17.51 \mathrm{de}$ & $46 \mathrm{cdef}$ & $36 \mathrm{ab}$ & $31 \mathrm{bc}$ & 5.17 & 0.00 & SD & Oblong \\
\hline AVTO1955-9 & $58 \mathrm{bc}$ & $60 \mathrm{ab}$ & $10.22 \mathrm{acd}$ & 10.16 ace & $48 \mathrm{cdef}$ & $39 \mathrm{ab}$ & 39 cde & 4.97 & 0.00 & $\mathrm{SD}$ & Oblong \\
\hline CLN1621L & $37 \mathrm{ac}$ & $70 \mathrm{ab}$ & 12.42 ae & $12.29 \mathrm{acd}$ & $40 \mathrm{bdf}$ & $37 \mathrm{ab}$ & $27 \mathrm{abd}$ & 4.34 & 0.00 & $\mathrm{D}$ & Round \\
\hline H7996 & $42 \mathrm{ab}$ & $42 \mathrm{a}$ & $17.07 \mathrm{de}$ & 15.04 bce & $39 \mathrm{bf}$ & $38 \mathrm{ab}$ & $32 \mathrm{bc}$ & 5.26 & 0.00 & $\mathrm{SD}$ & Round \\
\hline CRA66 & $59 \mathrm{~b}$ & $43 \mathrm{a}$ & $7.88 \mathrm{ac}$ & $7.76 \mathrm{ac}$ & $33 \mathrm{ab}$ & $36 \mathrm{ab}$ & $24 \mathrm{ab}$ & 5.40 & 0.00 & I & Round \\
\hline CLN4018I & $52 \mathrm{bc}$ & $66 \mathrm{ab}$ & 20.29 e & $19.55 \mathrm{~d}$ & $50 \mathrm{dg}$ & $53 c$ & $75 \mathrm{f}$ & 4.64 & 1.25 & SD & Round \\
\hline Mean & 51 & 55 & 11.72 & 11.01 & $43^{\circ}$ & 37 & 33 & 5.08 & 2.62 & - & - \\
\hline Entry mean square & $* * *$ & $* * * *$ & $* * *$ & $* * *$ & $* * * *$ & $* *$ & $* * *$ & ns & ns & - & - \\
\hline $\mathrm{CV} \%$ & 21.64 & 27.98 & 42.31 & 42.16 & 12.81 & 14.01 & 20.52 & 16.24 & 24.05 & - & - \\
\hline $\operatorname{LSD}(p=0.05)$ & 10.95 & 15.30 & 4.75 & 4.62 & 5.73 & 5.29 & 6.72 & 0.85 & 0.03 & & \\
\hline
\end{tabular}

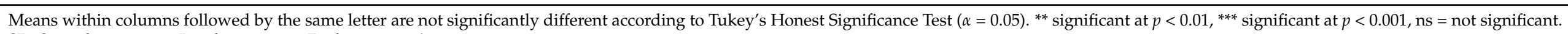
SD: Semi determinate, I: indeterminate, D: determinate). 

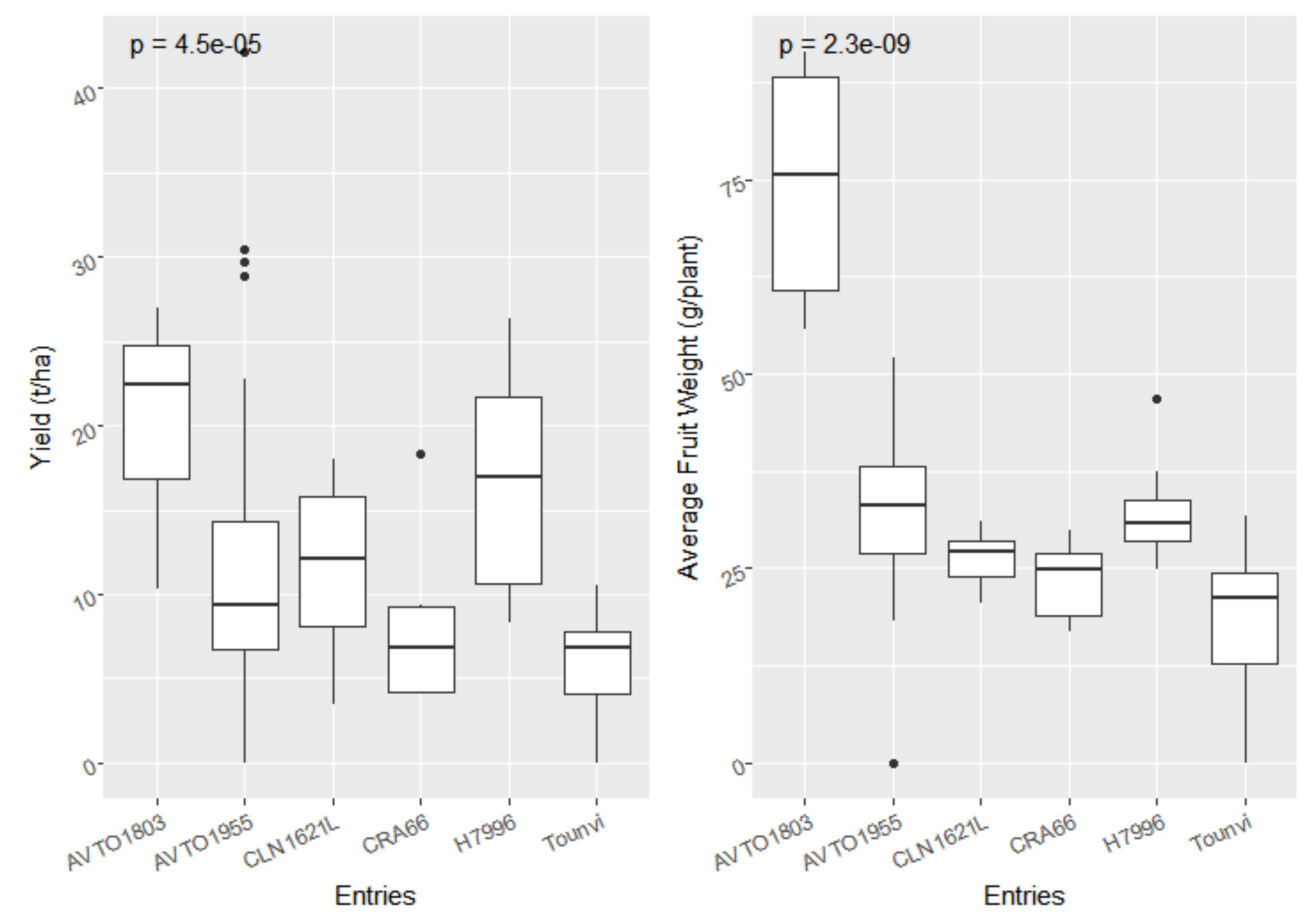

Figure 2. Comparison of the yield and average fruit weights of grouped AVTO (F5 lines) to the checks.

Differences were noted among entries for growth habit, fruit shape and color (Table 3). Seventeen entries were semi-determinates, five were indeterminates and one entry was determinate. Entry fruit shape was either oblong $(n=18)$ or round $(n=5)$. External and internal fruit colors were red.

\subsection{Characterization/Identification of R. solanacearum Complex Species and Phylotypes}

To test for the presence the bacterium in the stem of each line, we collected samples of 18 of the F5 lines and five checks from both experiments; only AVTO1955-5 and CRA 66 were positive (having the bacterium in the stem) but did not show wilting in the field. The other lines tested negative. Ten final samples were screened with five samples from the WorldVeg site, four samples from GBioS and one additional wilted tomato sample, which was collected at the WorldVeg site but out of the trial and included as check. Results showed that all the collected strains from both locations were phylotype I (Table 4). Three sequevars (I-14, I-18 and I-31) were identified in trial sites. The check sample was identified as sequevar I-14 from phylotype I. 


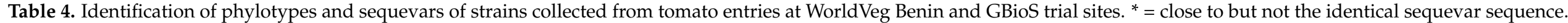

\begin{tabular}{|c|c|c|c|c|c|c|c|c|c|}
\hline & Location & Crop & Entry Code & $\begin{array}{l}\text { Plant Status at } \\
\text { Collection }\end{array}$ & Organ & $\begin{array}{c}\text { Tobacco } \\
\text { Test }\end{array}$ & BW Positive & Phylotype PCR & Sequevar \\
\hline 1 & WorldVeg-Benin & Tomato & CRA66 & Not Wilted & collar & + & + & I & 31 \\
\hline 2 & WorldVeg-Benin & Tomato & CLN1621L & Wilted & Collar/Diseased plant & + & + & I & $14^{*}$ \\
\hline 4 & WorldVeg-Benin & Tomato & AVTO1955-5 & Not Wilted & Collar/health plant & + & + & I & $14^{*}$ \\
\hline 5 & WorldVeg-Benin & Tomato & AVTO1955-5 & Not Wilted & Collar/health plant & + & + & I & $14^{*}$ \\
\hline 6 & University of Abomey-Calavi & Tomato & Tounvi 1 & Wilted & Collar/Diseased plant & + & + & I & 18 * \\
\hline 7 & University of Abomey-Calavi & Tomato & Tounvi 1 & Wilted & Pure culture & + & + & I & $18 *$ \\
\hline 9 & University of Abomey-Calavi & Tomato & Tounvi 2 & Wilted & Pure culture & + & + & I & $14^{*}$ \\
\hline 10 & $\begin{array}{l}\text { WorldVeg-Benin (off trial } \\
\text { site)(Check) }\end{array}$ & Tomato & ENZA 2 & Wilted & collar & + & + & I & $14^{*}$ \\
\hline
\end{tabular}




\section{Discussion}

Several varieties of tomato have been developed and/or introduced for cultivation in West Africa, including Benin. However, most of these varieties are hybrids and seeds are very expensive compared to the local varieties. Very few of these varieties are available in input supply stores and local markets. In southern Benin markets, for example, only local varieties (Tounvi, Akikon) and improved varieties (Thorgal F1, and Mongal F1 from Technisem seed company) are common [28]. Although local varieties are highly appreciated for early maturity, productivity and fruit quality by farmers and consumers, they are susceptible to BW, which makes their cultivation very difficult for farmers in many parts of Benin. Several vegetable seed companies are active in Benin but are evaluating hybrids bred in Asia or other regions for adaptation in West Africa; few are actively developing new locally adapted, BW-resistant varieties. BW-resistant hybrids developed in Asia and Europe such as Padma F1 (East West Seeds) and Mongal F1 (Technisem) are available in Benin and some other parts of West Africa [29], but there is a critical need to identify BW-resistant lines that could be candidates for use as open-pollinated varieties in the region.

In this study, the local variety Tounvi was highly susceptible to bacterial wilt caused by the $R$. solanacearum species complex; Tounvi was tested and found to lack resistance alleles at Bwr-6 and Bwr-12 regions. The F5 lines evaluated in the trials were developed in Taiwan using marker-assisted selection (MAS) for Bwr-12 and Bwr-6 genomic regions previously associated with BW resistance [21]. The F5 lines demonstrated high levels of BW tolerance/resistance in the trials; however, further testing in other Benin locations considered as BW hotspots is needed to confirm resistance. Sikirou et al. [4] reported high BW incidence due to RSSC infection in the Valley de l'Ouémé, a flood-prone area in Benin that was an important tomato production area. BW-tolerant varieties would facilitate the expansion of tomato production in this area. Additional testing of these lines in "hotspots" in other parts of West Africa would provide additional insights on stability of BW tolerance. These lines could be useful to public and private tomato breeding programs as sources of BW tolerance to develop new, locally-adapted open-pollinated varieties and hybrids. Local seed companies developing tomato varieties would benefit from adoption of marker-assisted selection for BW resistance. MAS protocols to select for Bwr-12 and Bwr-6 are straightforward and their use vastly improves the efficiency of selection for BW tolerance when combined with field trials. The African Vegetable Breeding Consortium (AVBC), established in 2018 through the World Vegetable Center and the African Seed Trade Association (AFSTA), would be an appropriate platform to train local breeders in BW resistance breeding, as well as other technologies and knowledge to develop improved locally adapted vegetable varieties. F5 lines AVTO1955-6, AVTO1955-3, AVTO1955-14 and AVTO1955-10 showed good performance not only in terms of resistance to BW but high yield and good fruit characteristics (fruit weight, length and width, color and shape). AVTO1803 (CLN4018I), homozygous for Bwr-12 and Bwr-6, demonstrated high levels of BW tolerance, high yield and good fruit traits and could be considered for variety release or use in breeding.

Grafting of susceptible tomato cultivars such as Tounvi onto resistant rootstocks has been applied to manage tomato BW in other parts of the world and could be an effective means to manage BW in Benin. In this study, no wilting was observed with checks Hawaii 7996 and CRA66, both of which have shown stable and durable resistance against various strains of the species complex $[30,31]$ in other parts of the world $[5,32]$. Our results suggest that H7996 and CRA66 may be tolerant to RSSC strains in Benin but more testing is needed to confirm this. Use of H7996 and CRA66 as rootstocks may allow production of the popular but BW-susceptible local variety Tounvi in BW-infested fields. Some of the F5 lines may also have potential as rootstocks and would help diversify rootstocks used for grafting in West Africa. Production of grafted seedlings adds costs and training is needed to help farmers and seedling nurseries produce them efficiently at reasonable costs.

Sikirou et al. [4] found that strains identified as RSSC in Benin were more widely distributed in the south than the center and the north of the country. Based on biochemical 
characteristics, Beninese RSSC strains were grouped into biovar I/race1 and biovar III/race 1. The endoglucanase sequences detected in samples from our trials were associated with phylotype I. A recent study in Togo, Benin's neighbor to the west, showed that all isolates collected from tomato belonged to the phylotype I [11]. Within each phylotype, strains can be further subclassified into sequevars based on the similarity of a $750 \mathrm{bp}$ fragment of the egl gene [33]. Phylotype I is known for its broad intrasubspecific diversity and comprises 16 out of the 57 sequevars that are currently known [10]. Phylotype I strains identified in this study were classified as sequevars I-14, I-18 and I-31. Sequevars I-14 and I-18 were reported in Taiwan [34] and sequevar I-31 in Mayotte Island [10]. Sequevar I-14 seems to be a sequevar common to both sites and this needs to be confirmed after checking larger sample numbers collected from larger parts of Benin. These results will guide in the development of tomato lines/varieties with resistance to the phylotype I RSSC strains present in Benin and in other regions with prevailing distribution of the phylotype I.

\section{Conclusions}

This study evaluated the resistance of tomato lines to bacterial wilt caused by Ralstonia solanacearum species complex in Benin and identified promising lines with good fruit yield and yield components. Sources of resistance to bacterial wilt were identified. AVTO1955-6, AVTO1955-3, AVTO1955-14, AVTO1955-10 and AVTO1803 showed high BW tolerance and good agronomic performance and fruit traits. These lines can be further released as variety or for use in breeding programs. Phylotype I strains of sequevars I-14, I-18 and I-31 were identified in our trials. Breeding for bacterial wilt resistance in Benin should consider phylotype I as target strains and grafting can be another option to manage bacterial wilt in the region.

Author Contributions: Conceptualization, P.H., H.Z., A.Q., J.H. and E.A.-D.; Funding acquisition, P.H.; Investigation, H.Z., A.Q., J.H., J.-R.C., E.A.-D., L.K. and P.H.; Methodology, H.Z.; Writingoriginal draft, H.Z., A.Q. and J.H.; Writing-review and editing, H.Z., J.-R.C., E.A.-D., L.K. and P.H. All authors have read and agreed to the published version of the manuscript.

Funding: Funding for this research was provided by UK aid from the UK government and the project "Developing and delivering agricultural technologies and knowledge to reduce poverty and hunger, and support adaptation to climate change", and by long-term strategic donors to the World Vegetable Center: Taiwan, United States Agency for International Development (USAID), Australian Centre for International Agricultural Research (ACIAR), Germany, Thailand, Philippines, Korea and Japan.

Institutional Review Board Statement: Not applicable.

Informed Consent Statement: Not applicable.

Data Availability Statement: Data available in a publicly accessible repository. All data collected during this experiment were deposited in the World Vegetable Center repository, HARVEST (https: / / worldveg.org/harvest) and are available to the public.

Acknowledgments: We appreciate the excellent work of the field technicians involved in trials management and data collection. We are thankful to Azoma Komla for the help in the trial implementation and data collection. We are also thankful to Sikirou Rachidatou and Epiphane Dossoumou for their help during the collection of the samples of wilted plants and FTA cards preparation.

Conflicts of Interest: The authors declare no conflict of interest.

\section{References}

1. FAOSTAT. Database, F. Crops. Food and Agriculture Organization of the United Nation. 2020. Available online: http://www.fao. org/faostat/en/\#data/QC (accessed on 6 April 2021).

2. Agossou, G.; Ahouansou, T.; Aly, D.; Assogba-Komlan, F. Etude sur la Promotion de la Filière des Cultures Maraîchères au Bénin. Rapport Principal; Ministry of Agriculture, Livestocks and Fisheries of Republic of Benin (MAEP): Cotonou, Benin, $2001 ;$ p. 102.

3. James, B.; Atcha-Ahowé, C.; Godonou, I.; Baimey, H.; Goergen, H.; Sikirou, R.; Toko, M. Integrated Pest. Management in Vegetable Production: A Guide for Extension Workers in West. Africa; International Institue of Tropical Agriculture (IITA): Ibadan, Oyo, Nigeria, 2010; p. 120. 
4. Sikirou, R.; Beed, F.; Ezin, V.; Hoteigni, J.; Miller, S.A. Distribution, pathological and biochemical characterization of Ralstonia solanacearum in Benin. Ann. Agric. Sci. 2017, 62, 83-88. [CrossRef]

5. Kunwar, S.; Hsu, Y.C.; Lu, S.F.; Wang, J.F.; Jones, J.B.; Hutton, S.; Paret, M.; Hanson, P. Characterization 3333 of tomato (Solanum lycopersicum) accessions for resistance to phylotype I and phylotype II strains of the Ralstonia solanacearum species complex under high temperatures. Plant Breed. 2020, 139, 389-401. [CrossRef]

6. Lebeau, A.; Daunay, M.-C.; Frary, A.; Palloix, A.; Wang, J.-F.; Dintinger, J.; Chiroleu, F.; Wicker, E.; Prior, P. Bacterial wilt resistance in tomato, pepper, and eggplant: Genetic resources respond to diverse strains in the Ralstonia solanacearum species complex. Phytopathology 2011, 101, 154-165. [CrossRef] [PubMed]

7. Prior, P.; Fegan, M. Diversity and molecular detection of Ralstonia solanacearum race 2 strains by multiplex PCR. In Bacterial Wilt Disease and the Ralstonia Solanacearum Species Complex; American Phytopathological Society (APS Press): St. Paul, MN, USA, 2005; pp. 405-414.

8. Safni, I.; Cleenwerck, I.; De Vos, P.; Fegan, M.; Sly, L.; Kappler, U. Polyphasic taxonomic revision of the Ralstonia solanacearum species complex: Proposal to emend the descriptions of Ralstonia solanacearum and Ralstonia syzygii and reclassify current R. syzygii strains as Ralstonia syzygii subsp. syzygii subsp. nov., R. solanacearum phylotype IV strains as Ralstonia syzygii subsp. indonesiensis subsp. nov., banana blood disease bacterium strains as Ralstonia syzygii subsp. celebesensis subsp. nov. and R. solanacearum phylotype I and III strains as Ralstoniapseudosolanacearum sp. nov. Int. J. Syst. Evol. Microbiol. 2014, 64, 3087-3103.

9. Prior, P.; Ailloud, F.; Dalsing, B.L.; Remenant, B.; Sanchez, B.; Allen, C. Genomic and proteomic evidence supporting the division of the plant pathogen Ralstonia solanacearum into three species. BMC Genom. 2016, 17, 1-11. [CrossRef]

10. Chesneau, T.; Maignien, G.; Boyer, C.; Cheron, J.-J.; Roux-Cuvelier, M.; Vanhuffel, L.; Poussier, S.; Prior, P. Sequevar diversity and virulence of Ralstonia solanacearum phylotype I on Mayotte Island (Indian Ocean). Front. Plant Sci. 2018, 8, 2209. [CrossRef] [PubMed]

11. Sanju., K.; Bamazi, B.; Banito, A.; Carter, M.; Weinstein, S.; Steidl, O.; Hayes, M.M.; Allen, C.; Paret, M. First Report of Bacterial Wilt Disease of Tomato, Pepper, and Gboma Caused by Ralstonia solanacearum Species Complex in Togo. Plant Dis. 2020. [CrossRef]

12. Bihon, W.; Chen, J.-R.; Kenyon, L. Identification and characterization of Ralstonia spp. causing bacterial wilt disease of vegetables in Mali. J. Plant Pathol. 2020, 102, 1029-1039. [CrossRef]

13. N'Guessan, C.A.; Abo, K.; Fondio, L.; Chiroleu, F.; Lebeau, A.; Poussier, S.; Wicker, E.; Koné, D. So near and yet so far: The specific case of Ralstonia solanacearum populations from Cote d'Ivoire in Africa. Phytopathology 2012, 102, 733-740. [CrossRef]

14. Adebayo, O.; Ekpo, E. Biovar of Ralstonia solanacearum causing bacterial wilt of tomato in Nigeria. Plant Dis. 2005, 89, 1129. [CrossRef]

15. Scott, J.; Wang, J.; Hanson, P. Breeding tomatoes for resistance to bacterial wilt, a global view. In Proceedings of the I International Symposium on Tomato Diseases 695, Orlando, FL, USA, 4 June 2005.

16. Hanson, P.M.; Wang, J.-F.; Licardo, O.; Mah, S.Y.; Hartman, G.L.; Lin, Y.-C.; Chen, J.-T. Variable reaction of tomato lines to bacterial wilt evaluated at several locations in Southeast Asia. HortScience 1996, 31, 143-146. [CrossRef]

17. Wang, J.-F.; Hanson, P.; Barnes, J. Worldwide evaluation of an international set of resistance sources to bacterial wilt in tomato. In Bacterial Wilt Disease; Prior, P., Allen, C., Elphinstone, J., Eds.; Springer: Heidelberg/Berlin, Germany, 1998; pp. 269-275.

18. Scott, J. Tomato improvement for bacterial disease resistance for the tropics: A contemporary basis and future prospects. In Proceedings the First International Conference on the Processing Tomato and First International Symposium on Tropical Tomato Diseases; Pernambuco, Brazil, 18-21 November 1996, ASHS Press: Alexandria, VA, USA, 1997.

19. Opena, R.; Hartman, G.; Chen, J.; Yang, C. Breeding for Bacterial wilt Resistance in Tropical Tomato; Asian Vegetable Reseacrh and Development Center: Tainan, Taiwan, 1990.

20. Walter, J. Hereditary resistance to disease in tomato. Annu. Rev. Phytopathol. 1967, 5, 131-160. [CrossRef]

21. Wang, J.-F.; Ho, F.-I.; Truong, H.T.H.; Huang, S.-M.; Balatero, C.H.; Dittapongpitch, V.; Hidayati, N. Identification of major QTLs associated with stable resistance of tomato cultivar 'Hawaii 7996' to Ralstonia solanacearum. Euphytica 2013, 190, 241-252. [CrossRef]

22. Ho, F.; Chung, C.; Wang, J. Distribution of Major QTLs Associated with Resistance to Ralstonia Solanacearum Phylotype I Strain in a Global set of Resistant Tomato Accessions. In Report of the Tomato Genetics Cooperative; Hal Inrae: Ithaca, NY, USA, 2013; pp. 22-30.

23. Hanson, P.; Lu, S.-F.; Wang, J.-F.; Chen, W.; Kenyon, L.; Tan, C.-W.; Tee, K.L.; Wang, Y.-Y.; Hsu, Y.-C.; Schafleitner, R. Conventional and molecular marker-assisted selection and pyramiding of genes for multiple disease resistance in tomato. Sci. Hortic. 2016, 201, 346-354. [CrossRef]

24. Safni, I.; Subandiyah, S.; Fegan, M. Ecology, epidemiology and disease management of Ralstonia syzygii in Indonesia. Front. Microbiol. 2018, 9, 419. [CrossRef] [PubMed]

25. Burlakoti, R.R.; Hsu, C.-f.; Chen, J.-r.; Sheu, Z.-M.; Bihon, W.; Kenyon, L. Capture of Ralstonia solanacearum species complex strains directly from plant tissue sampled on FTA cards for molecular characterization. J. Plant Pathol. 2020, 102, 11-17. [CrossRef]

26. R Core Team. R: A Language and Environment for Statistical Computing; R Foundation for Statistical Computing: Vienna, Austria, 2018.

27. Hothorn, T.; Bretz, F.; Westfall, P.; Heiberger, R.M.; Schuetzenmeister, A.; Scheibe, S.; Hothorn, M.T. Package 'multcomp'. In Simultaneous Inference in General Parametric Models; Project for Statistical Computing: Vienna, Austria, 2016. 
28. Adegbola, Y.; Ahoyo Adjovi, N.; Adekambi, S.; Zossou, R.; Sonehekpon, E.; Assogba Komlan, F.; Djossa, E. Consumer preferences for fresh tomatoes in Benin using a conjoint analysis. J. Int. Food Agribus. Mark. 2019, 31, 1-21. [CrossRef]

29. Traore, O.; Wonni, I.; Boro, F.; Somtore, E.; Zombré, C.T.; Dianda, O.Z.; Wicker, E.; Ilboudo, P.; Ouedraogo, L.S.; Somda, I. Evaluation of the 19 varieties and accessions of tomato against bacterial wilt in Bobo-Dioulasso, Burkina Faso. Int. J. Biol. Chem. Sci. 2020, 14, 2870-2879. [CrossRef]

30. Baichoo, Z.; Jaufeerally-Fakim, Y. Ralstonia solanacearum upregulates marker genes of the salicylic acid and ethylene signaling pathways but not those of the jasmonic acid pathway in leaflets of Solanum lines during early stage of infection. Eur. J. Plant Pathol. 2017, 147, 615-625. [CrossRef]

31. Shin, I.S.; Hsu, J.-C.; Huang, S.-M.; Chen, J.-R.; Wang, J.-F.; Hanson, P.; Schafleitner, R. Construction of a single nucleotide polymorphism marker based QTL map and validation of resistance loci to bacterial wilt caused by Ralstonia solanacearum species complex in tomato. Euphytica 2020, 216, 54. [CrossRef]

32. Daunay, M.-C.; Laterrot, H.; Scott, J.; Hanson, P.; Wang, J. Tomato resistance to bacterial wilt caused by Ralstonia solanaearum EF Smith: Ancestry and peculiarities. In Report of the Tomato Genetics Cooperative; Hal Inrae: La Colle sur Loup, France, 2010.

33. Ailloud, F.; Lowe, T.; Cellier, G.; Roche, D.; Allen, C.; Prior, P. Comparative genomic analysis of Ralstonia solanacearum reveals candidate genes for host specificity. BMC Genom. 2015, 16, 1-11. [CrossRef] [PubMed]

34. Lin, C.H.; Tsai, K.C.; Prior, P.; Wang, J.F. Phylogenetic relationships and population structure of R alstonia solanacearum isolated from diverse origins in T aiwan. Plant Pathol. 2014, 63, 1395-1403. [CrossRef] 